\title{
High Concentration of Reticular Fibers in Periurethral Region of the Prostatic Urethra from Patients with Benign Prostatic Hyperplasia as Revealed by Stereology
}

\author{
Alta Concentración de Fibras Reticulares en la Región Periuretral de la Uretra Prostática \\ de Pacientes con Hiperplasia Prostática Benigna Revelada por Estereología
}

\author{
"Jorge H. M. Manaia; **Waldemar S. Costa; "*Francisco J. B. Sampaio; \\ ${ }^{* *}$ Marcelo A. Figueiredo; "Gilberto P. Cardoso \& *,"** Marcio A. Babinski
}

MANAIA, J. H. M.; COSTA, W. S.; SAMPAIO, F. J. B.; FIGUEIREDO, M. A.; CARDOSO, G. P. BABINSKI, M. A. High concentration of reticular fibers in periurethral region of the prostatic urethra from patients with benign prostatic hyperplasia as revealed by stereology. Int. J. Morphol., 30(3):1177-1181, 2012.

SUMMARY: The goal of this investigation was to analyze and quantify changes of the reticular fibers in the prostatic urethra of patients with benign prostatic hyperplasia (BPH) and compare with a control group. Prostatic urethra tissue samples were obtained from ten patients (age range 65 to 79 years, mean 66) with clinical symptoms of bladder outlet obstruction who had undergone open prostatectomy. The ten control group samples (urethral tissue samples from the transitional zone) were collected from prostates obtained during autopsy of accidental death adults of less than 25 years. The Vv of the reticular fibers was determined with stereologic methods from 25 random fields per sample using the point-count method with a M-42 grid test system. The quantitative data were analyzed using the KolmogorovSmirnov and Mann-Whitney U tests. The Vv (mean \pm SD) in the control and BPH groups respectively were: $23.4 \pm 1.8$ and $30.3 \pm 1.2$ (0.001). BPH cause significant increase of reticular fibers in prostatic urethra.

KEY WORDS: Prostatic urethra; Reticular fibers; Stereology.

\section{INTRODUCTION}

The benign prostatic hyperplasia (BPH) is urological disorder, most common in men over 50 years of age (Berry et al., 1984; Chagas et al., 2002), is associated with complex, not well understood, interactions between acinar epithelial cells and their supportive stroma (Costa et al., 2004; Babinski et al., 2003; 2007). Epithelial-stromal interactions and stromal extra cellular matrix (ECM) components also play key roles in normal prostate physiology and in tumor growth (nodules) (Cunha, 1994; Nagle, 2004).

The majority of the TZ prostatic urethral injuries have a compressive origin from the BPH mass (McNeal, 1978; Roehrborn \& McConnell, 2002; Chagas et al.; Costa et al.), thus, the nodular growth occurs in the TZ in $>70 \%$ of the cases and compresses the prostatic urethra resulting in bladder outlet obstruction (BOO) (McNeal, 1978, 1990, 1997). It is well known that $\mathrm{BOO}$ in $\mathrm{BPH}$ results from mechanical obstruction by the enlarged prostate and the tone of the prostate smooth muscles in the prostatic tissue (Caine, 1986; Ichiyanagi et al., 1999). As a consequence of these changes, lower urinary tract symptoms (LUTS) in men usually occur and are considered a consequence of $\mathrm{BOO}$ due to BPH (Ichiyanagi et al.).

The extracellular matrix of the prostatic urethra has received less attention than smooth muscle disposition and innervation (Dorschner et al., 2001; Yucel \& Baskin, 2004; Karam et al., 2005). So, the structure of this region has still not been properly studied in the normal prostatic urethra, nor compared with hyperplastic samples. A better knowledge of the histological components in the normal and the hyperplasic prostatic urethra is necessary. Thus we studied the volumetric density (Vv) of the fibroelastic element (reticular fibers) in the prostatic urethral samples from patients with BPH mass and control (normal) groups, to define the role of the extracellular matrix components in LUTS.

\footnotetext{
* Department of Morphology, Biomedical Center, Fluminense Federal University, Rio de Janeiro, Brazil.

** Urogenital Research Unit, Biomedical Center, State University of Rio de Janeiro, Rio de Janeiro, Brazil.
} 
MANAIA, J. H. M.; COSTA, W. S.; SAMPAIO, F. J. B.; FIGUEIREDO, M. A.; CARDOSO, G. P. BABINSKI, M. A. High concentration of reticular fibers in periurethral region of the prostatic urethra from patients with benign prostatic hyperplasia as revealed by stereology. Int. J. Morphol., 30(3):1177-1181, 2012.

\section{MATERIAL AND METHOD}

Ethics procedures. This study complies with the provisions of the Declaration of Helsinki in 1995 (as revised in Edinburgh, 2000). Our Internal Review Board approved study guidelines. Also, the protocol received approval by the Ethics Committee on Human Research of the State University of Rio de Janeiro. All patients provided written informed consent for the use of prostatic tissue material for research prior to inclusion in the study.

Groups and samples. BPH tissue samples of the transitional zone of the urethra were obtained from ten patients without symptoms of $\mathrm{BOO}$ who did not undergo any treatment for symptomatic BPH. Each patient had undergone open prostatectomy (retropubic or transvesicular). All patients studied had prostates larger than 40g (mean 60), a flow rate of $12 \mathrm{~mL} / \mathrm{s}$ and an International Prostate Symptom Score (IPSS) of 12 or greater. Patient age range was 63 to 79 years (mean 66) and all patients had shown histological diagnosis of BPH with no foci of prostatic carcinoma.

The control samples were obtained from autopsies of young males ranging in age from 18 to 30 years (mean 24), who died of unrelated causes to the urogenital system. Samples were taken from the transitional zone of the urethra of ten prostates. A sagittal section from the anterior region to the lumen of the prostatic urethra was taken exposing the verumontanum. This anatomic landmark was used to excise urethral fragments $(1 \mathrm{X} 1 \mathrm{~cm})$ accurately from the transition zone (McNeal, 1978; 1990). The time elapsed between death and fixation of the excised controls was less than six hours.

Histological procedures and morphometrical method. The samples of prostatic urethra tissue were immersed in $10 \%$ formalin solution for 24 hours and then embedded in paraffin. All samples were initially stained with hematoxylineosin and examined by a pathologist to detect any foci of carcinoma and to exclude samples with artifacts. A pathologist from the University Hospital, who was not involved in the research protocol, analyzed the prostate samples obtained in the surgical unit. Then, a pathologist from the Urogenital Research Unit confirmed the diagnosis.
From each prostate, five different samples of the prostatic urethra were taken from the transitional zone. From each sample, five different sections were selected. Five random fields were evaluated from each section, resulting in the analysis of 25 test areas from each prostatic urethra, totaling 250 fields that were analyzed for reticular fibers in each group. For the stereologic analysis, the $5 \mu \mathrm{m}$ sections were stained with the Gomori's reticulin.

The analyzed fields were then digitized to a final magnification of X400 using a video camera coupled to a light microscope (BH-2 Olympus). The selected histological areas were then quantified by applying a test-grid system (M42) on the digitized fields on the screen of a color monitor (Sony). From stereologic principles in isotropic tissue, the area distribution of a given structure, as determined on a twodimensional section of the structure, is proportional to the volume distribution of the structure. The volume density of the histological components was calculated as $\mathrm{Vv}=\mathrm{Pp} / \mathrm{Pt}$, where $\mathrm{Vv}$ was the volume density, $\mathrm{p}$ was the tissue component under consideration, $\mathrm{Pp}$ was the number of test points associated with $\mathrm{p}$, and Pt was the number of points in the test system. The stereologic methods have been described in detail previously (Weibel et al., 1966; Gundersen et al., 1988).

Statistical analysis. The data were analyzed using the Kolmogorov-Smirnov test to verify normal distribution (Gaussian) and variance of data, as well as, the unpaired test to demonstrate whether the $\mathrm{Vv}$ differences were statistically significant. $\mathrm{P} \leq 0.05$ was considered statistically significant.

\section{RESULTS}

The reported findings are exclusively of the transitional zone of the assessed human prostatic urethras. In control group, beneath the mucosa, the sub mucosa was observed containing reticular fibers interspersed with smooth muscle (Fig.1). In the BPH group, reticular fibers presented disorders in the prostatic urethra (Fig.2) with statistically, significant increase no $\mathrm{Vv}$ of this fibers. The relative values (\% mean $\pm \mathrm{SD})$ of the quantitative evaluation in both groups are shown in Table I.

Table I. Results of reticular fibers, quantitative evaluation (volumetric density) in prostatic urethra transitional zone.

\begin{tabular}{lccc}
\hline Element $\quad$ Controls & BPH Urethra & N & P Value \\
\hline $\begin{array}{l}\text { Reticular Fiber } \\
\text { Data presented as the mean percentage } \pm \text { SD. }\end{array}$ & $30.4 \pm 1.2$ & 10 & $0.001 *$ \\
* Statistically significant, Mann-Whitney U test. & & & \\
\hline
\end{tabular}

Data presented as the mean percentage \pm SD. * Statistically significant, Mann-Whitney U test. 


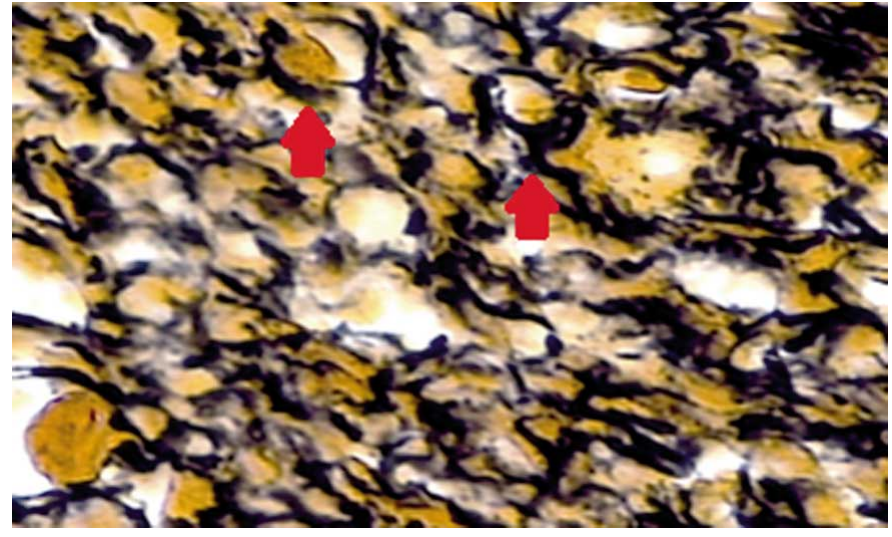

Fig. 1. Photomicrograph of a transition zone prostatic urethra section from control group illustrating the reticular fibers arrangement (red arrows) in sub mucosa layer. Note their variable thickness. Gomori's reticulin staining, original magnification X40.

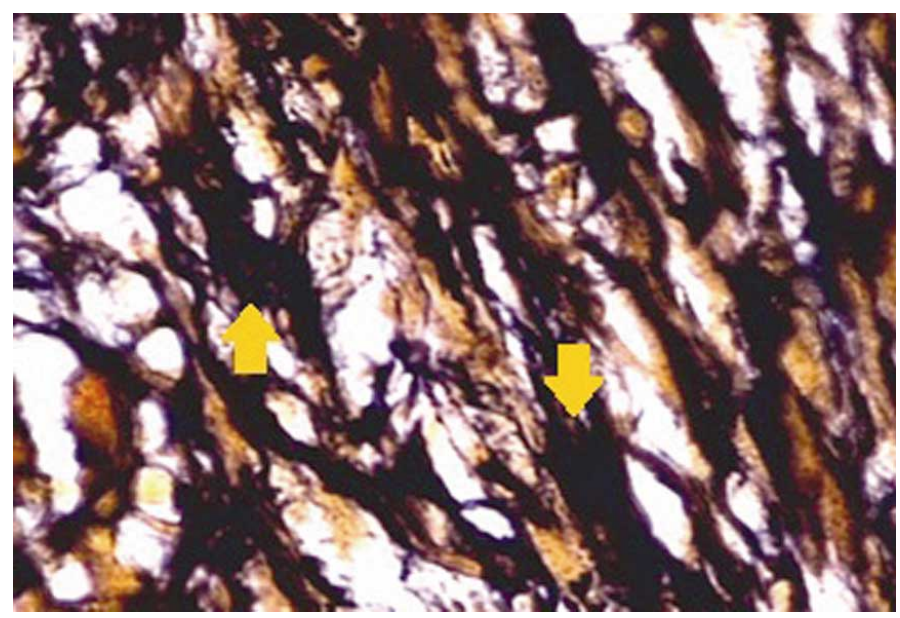

Fig. 2. Photomicrograph of prostatic urethra from patient in BPH group showing damage stroma with increase of reticular fibers (yellow arrows). Note in some areas, the fibers are disorganized. Gomori's reticulin staining, original magnification $\mathrm{X} 40$.

\section{DISCUSSION}

The prostatic urethra is lined by transitional epithelium (Tanagho \& McAninch, 2000). Regional differences may exist and vary from squamous, stratified or pseudostratified columnar epithelium (Orlandini \& Orlandini, 1989). These variations may extend into the prostatic ducts (Roehrborn \& McConnell). It is primarily composed of a mucosal layer covered by urothelium. Beneath the basal membrane a layer of connective tissue (submucosa) (Tanagho \& McAninch) contains vascular sinusoids, cells (mainly fibroblasts), an extracellular matrix of collagen, proteoglycans, reticular and elastic fibers, glycoproteins and an inner longitudinal and an outer circular layer of smooth muscle (Tanagho \& McAninch; Bastos et al., 2004; Dorschner et al.; Yucel \& Baskin).
The prostatic transitional zone (TZ) is particularly relevant when considering prostate pathology. Thus, there are several conflicting opinions concerning the relationship between the size of the hyperplastic prostate and the grade of urethral compression (Shapiro et al., 1992; Kaplan et al., 1995; Terris et al., 1998; Ichiyanagi et al.). The relationship between the International Prostate Symptom Score (IPSS) and the prostate total volume suggests that the bigger prostate impinges more making the symptoms more severe (Kojima et al., 1997). On the other hand, the lack of relationship between the total prostatic volume and BOO suggests that the symptoms and urodynamic outcomes of the infra-vesical obstruction from HPB is more associated to the enlargement of the prostatic transitional zone than to the total prostatic volume (Kaplan et al.; Terris et al.; Ichiyanagi et al.). The relationship between the histological changes in the prostatic urethra and the beginning of the obstructive symptoms is not completely recognized.

The extracellular matrix is very important in the development of tissues and organs, rebuilding and repair of damages, and maintenance of the tissue normality (Kielty et al., 2002; Hay, 1991; Eckes et al., 2000). Therefore, the location and arrangement of the extracellular matrix can be associated with the functional features of each kind of tissue, pointing out their particular biomechanical proprieties (Kielty et al.; Hay; Eckes et al.). Changes in the elements of the extracellular matrix of an organ also change these proprieties (Peters et al., 1997; da Silva et al., 2002). The observed human male urethras presented a uniform gross anatomical appearance, while changes in the extracellular matrix could be noted in its various segments (membranous, spongy and glandular), justifying the functional (Hsu et al., 1994; da Silva et al.) and pathological differences (Singh \& Blandy, 1976; Baskin et al., 1993; da Silva et al.). A significant increase of reticular fibers was found. The external pressure from the hyperplastic nodules of the transitional zone, probably, creates a urethral rebuilding. This process imposes a large urethral distension together with a characteristic increasing in length (longitudinal and antero-posterior axis) of the proximal prostatic urethra, damaging the mucosa and sub mucosa (McNeal, 1997). McNeal (1997) reported that this change could take place due to the urethral position between the two transitional zone masses. This could compress the urethra and create an enlargement in the urethral mucosa, which increases as much as the hyperplastic nodules expand. Thus, the fibrous elements of the extracellular matrix should have an important role in preservation of the normal structure of the prostatic urethra. However, this connection has not been related previously. 
MANAIA, J. H. M.; COSTA, W. S.; SAMPAIO, F. J. B.; FIGUEIREDO, M. A.; CARDOSO, G. P. BABINSKI, M. A. High concentration of reticular fibers in periurethral region of the prostatic urethra from patients with benign prostatic hyperplasia as revealed by stereology. Int. J. Morphol., 30(3):1177-1181, 2012.

The increasing of the reticular fibers affects the prostatic urethra by diminishing its resistance. The rebuilding process of the extracellular matrix is likely similar for the transitional zone parenchyma, from the response in the stromal hyperplastic nodules (Chagas et al.; Costa et al.). Hence, the utmost important modifications in the prostatic urethra in patients with BOO for HPB are in the extracellular matrix. These changes are associated to the great enlargement of urethra and the increasing of the external pressure from the prostatic hyperplastic nodules of the transitional zone (McNeal, 1972).

The results of this study offer new information about urethral morphology (McNeal, 1972; da Silva et al.), mainly with reference to damage of the prostatic urethra by the hyperplastic nodules of the prostatic transitional zone
(McNeal, 1997; Chagas et al.; Costa et al.; Babisnki et al., 2007) and the urodynamic outcome concerning BOO (Ishigooka et al., 1996; Gosling, 1997; Kojima et al.; Terris et al.; Ichiyanagi et al.; Inui et al., 1999). Briefly, the increasing reticular fibers could be associated with resistance and urethral complacency.

In conclusion, BPH nodules cause compression forces in prostatic urethra and consequently induces a remodeling process of the extracellular matrix with significant increase of reticular fibers in prostatic urethra.

ACKNOWLEDGEMENTS. This work was supported by grants from the Foundation for Research Support of Rio de Janeiro (FAPERJ), Brazil.

MANAIA, J. H. M.; COSTA, W. S.; SAMPAIO, F. J. B.; FIGUEIREDO, M. A.; CARDOSO, G. P. BABINSKI, M. A. Alta concentración de fibras reticulares en la región periuretral de la uretra prostática de pacientes con hiperplasia prostática benigna revelada por estereología. Int. J. Morphol., 30(3):1177-1181, 2012.

RESUMEN: El objetivo de esta investigación fue analizar y cuantificar los cambios de las fibras reticulares en la uretra prostática de pacientes con hiperplasia prostática benigna (HPB) y compararlo con un grupo control. Muestras de tejido de uretra prostática se obtuvieron de diez pacientes (rango de edad 65 a 79 años, media 66) con síntomas clínicos de obstrucción del tracto urinario inferior que se habían sometido a prostatectomía abierta. Las diez muestras del grupo de control (muestras uretrales de tejido de la zona de transición) se obtuvieron de próstatas durante la autopsia de sujetos adultos con muerte accidental menores de 25 años. El Vv de las fibras reticulares se determinó con métodos estereológicos de 25 campos al azar por muestra utilizando el método de valor de conteo con el sistema M-42. Los datos cuantitativos se analizaron mediante la prueba de KolmogorovSmirnov y Mann-Whitney U. El Vv (media \pm DE) en el grupo control y BPH, respectivamente, fueron: 23,4 $\pm 1,8$ y 30,3 \pm 1,2 (0,001). La BPH causó aumento significativo de fibras reticulares en uretra prostática.

PALABRAS CLAVE: Uretra prostática; Fibras reticulares; Estereología.

\section{REFERENCES}

Babinski, M. A.; Chagas, M. A.; Costa, W. S. \& Sampaio, F. J. Prostatic epithelial and luminal area in the transition zone acini: morphometric analysis in normal and hyperplastic human prostate. BJU Int., 92(6):592-6, 2003.

Babinski, M. A.; Costa, W. S.; Sampaio, F. J. B. \& Cardoso, L. E. M. Structural organization of fibrous connective tissue in the periacinar region of the transitional zone from normal human prostates as revealed by scanning electron microscopy. BJU Int., 100(4) :9404, 2007.

Baskin, L. S.; Constantinescu, S. C.; Howard, P. S.; McAninch, J. W.; Ewalt, D. H.; Duckett, J. W.; Snyder, H. M. \& Macarak, E. J. Biochemical characterization and quantitation of collagenous components of urethral stricture tissue. J. Urol., 150(2 Pt. 2):642-7, 1993.

Bastos, A. L.; Silva, E. A.; Silva Costa, W. \& Sampaio F.J. The concentration of elastic fibres in the male urethra during human fetal development. BJU Int., 94(4) :620-3, 2004.

Berry, S. J.; Coffey, D. S.; Walsh, P. C. \& Ewing, L. L. The development of human benign prostatic hyperplasia with age. J. Urol., 132(3):474-9, 1984.
Caine, M. The present role of alpha-adrenergic blockers in the treatment of benign prostatic hypertrophy. J. Urol., 136:1-4, 1986.

Chagas, M. A.; Babinski, M. A.; Costa, W. S. \& Sampaio, F. J. Stromal and acinar components of the transition zone in normal and hyperplastic human prostate. BJU Int., 89(7):699-702, 2002.

Costa, W. S.; de Carvalho, A. M.; Babinski, M. A.; Chagas, M. A. \& Sampaio, F. J. Volumetric density of elastic and reticular fibers in transition zone of controls and patients with benign prostatic hyperplasia. Urology, 64(4):693-7, 2004.

Cunha, G. R. Role of mesenchymal-epithelial interactions in normal and abnormal development of mammary gland and prostate. Cancer, 74(3 Suppl.):1030-44, 1994.

da Silva, E. A.; Sampaio, F. J.; Ortiz, V. \& Cardoso, L. E. Regional differences in the extracellular matrix of the human spongy urethra as evidenced by the composition of glycosaminoglycans. J. Urol., 167(5):2183-7, 2002.

Dorschner, W.; Stolzenburg, J. U. \& Neuhaus, J. Structure and function of the bladder neck. Adv. Anat. Embryol. Cell Biol., 159:III-XII, 1109, 2001. 
MANAIA, J. H. M.; COSTA, W. S.; SAMPAIO, F. J. B.; FIGUEIREDO, M. A.; CARDOSO, G. P. BABINSKI, M. A. High concentration of reticular fibers in periurethral region of the prostatic urethra from patients with benign prostatic hyperplasia as revealed by stereology. Int. J. Morphol., 30(3):1177-1181, 2012.

Eckes, B.; Zigrino, P.; Kessler, D.; Holtkotter, O.; Shephard, P.; Mauch, C. \& Krieg, T. Fibroblast-matrix interactions in wound healing and fibrosis. Matrix Biol., 19(4) :325-32, 2000.

Gosling, J. A. Modification of bladder structure in response to outflow obstruction and ageing. Eur. Urol., 32 Suppl., 1:9-14, 1997.

Gundersen, H. J. G.; Bendtsen, T. F.; Korbo, L.; Marcussen, L.; Moller, A.; Nielsen, K.; Nyengaard, J. R.; Pakkenberg, B.; Sorensen, B. \& Vesterby, A. Some new, simple and efficient stereological methods and their use in pathological research and diagnosis. APMIS, 96(5):379-94, 1988.

Hay, E. D. Cell Biology of Extracellular Matrix. $2^{\text {nd }}$ ed. New York, Plenum Press, 1991. pp.1-72.

Hsu, G. L.; Brock, B.; von Heyden, B.; Nunes, L.; Lue, T. F. \& Tanagho E. A. The distribution of elastic fibrous elements within the human penis. Br. J. Urol., 73(5):566-71, 1994.

Ichiyanagi, O.; Sasagawa, I.; Ishigooka, M.; Suzuki, Y. \& Nakada, T. Relationship between urodynamic type of obstruction and histological component of the prostate in patients with benign prostatic hyperplasia. Eur. Urol., 36(3):203-6, 1999.

Inui, E.; Ochiai, A.; Naya, Y.; Ukimura, O. \& Kojima, M. Comparative morphometric study of bladder detrusor between patients with benign prostatic hyperplasia and controls. J. Urol., 161(3):82730, 1999 .

Ishigooka, M.; Hayami, S.; Hashimoto, T.; Suzuki, Y. \& Katoh, T. Relative and total volume of histological components in benign prostate hyperplasia: relationship between histological components and clinical findings. Prostate, 29(2):77-82, 1996.

Kaplan, S. A.; Te, A. E.; Pressler, L. B. \& Olsson, C. A. Transition zone index as a method of assessing benign prostatic hyperplasia: correlation with symptoms, urine flow and detrusor pressure. $J$. Urol., 154(5):1764-7, 1995.

Karam, I.; Moudouni, S.; Droupy, S.; Abd-Alsamad, I.; Uhl, J. F. \& Delmas, V. The structure and innervation of the male urethra: histological and immunohistochemical studies with three-dimensional reconstruction. J. Anat., 206(4):395-403, 2005.

Kielty, C. M.; Sherratt, M. J. \& Shuttleworth, C. A. Elastic fibres. J. Cell Sci., 115(Pt. 14):2817-28, 2002

Kojima, N.; Naya, Y.; Inoque, W.; Ukimura, O.; Watanabe, M.; Saitoh, M. \& Watanabe, H. The American Urological Association Symptom index for benign prostatic hyperplasia as a function of age, volume and ultrasonic appearance of the prostate. J. Urol., 157(6):2160-5, 1997.

McNeal, J. E. The prostate and prostatic urethra: A morphologic synthesis. J. Urol., 107(6):1008-16, 1972.

McNeal, J. E. Origin and evolution of benign prostatic enlargement. Invest. Urol., 15(4):340-5, 1978.
McNeal, J. Pathology of benign prostatic hyperplasia: Insight into etiology. Urol. Clin. North Am., 17(3):477-86, 1990.

McNeal, J. E. Prostate. In: Sterenberg, S. S. (Ed.). Histology for Pathologists. $2^{\text {nd }}$ ed. Philadelphia, Lippincott-Raven, 1997. pp.9971017.

Nagle, R. B. Role of the extracellular matrix in prostate carcinogenesis. J. Cell. Biochem., 91(1):36-40, 2004.

Orlandini, S. Z. \& Orlandini, G. E. Ultrastructure of human male urethra. Arch. Androl., 23(1):51-9, 1989.

Peters, C. A.; Freeman, M. R.; Fernandez, C. A.; Shepard, J.; Wiederschain, D. G. \& Moses, M. A. Dysregulated proteolytic balance as the basis of excess extracellular matrix in fibrotic disease. Am. J. Physiol., 272(6 Pt. 2):R1960-5, 1997.

Roehrborn, C. G. \& McConnell, J. D. Etiology, pathophysiology, epidemiology and natural history of benign prostatic hyperplasia. In: Walsh, P. C.; Retik, A. B.; Vaughan. Jr. E. D. \& Wein, A. J. (Eds.). Campbell's Urology. 8th ed. Philadelphia, PA, WB Saunders Co., 2002. pp.1297-336.

Singh, M. \& Blandy, J. P. The pathology of urethral stricture. J. Urol., 115(6):673-6, 1976.

Shapiro, E.; Becich, M. J.; Hartanto, V. \& Lepor H. The relative proportion of stromal and epithelial hyperplasia is related to the development of symptomatic benign prostatic hyperplasia. J. Urol., 147(5):1293-7, 1992

Tanagho, E. A. \& McAninch, J. W. Smith's General Urology. $15^{\text {th }}$ ed. New York, McGraw-Hill, 2000. pp.31-40.

Terris, M. K.; Afzal, N. \& Kabalin, J. N. Correlation of transrectal ultrasound measurements of prostate and transition zone size with symptom score, bother score, urinary flow rate, and post-void residual volume. Urology, 52(3):462-6, 1998.

Weibel, E. R.; Kistler, G. S. \& Scherle, W. F. Practical stereological methods for morphometric cytology. J. Cell Biol., 30(1):23-38, 1966.

Yucel, S. \& Baskin, L. S. An anatomical description of the male and female urethral sphincter complex. J. Urol., 17(5):1890-7, 2004.

\section{Correspondence to:}

Prof. Dr. Marcio A. Babinski

Departamento de Morfologia, Instituto de Biomédico

Universidade Federal Fluminense (UFF)

Rua Ernani Mello, 101, São Domingos

CEP 24.210-150, Niterói, RJ

BRAZIL

Email: mababinski@gmail.com

Received: 15-03-2012

Accepted: 22-06-2012 